\title{
INTRODUCTION TO POLITICAL BIOGRAPHY IN LITERATURE AND CINEMA
}

\author{
DELPHINE LETORT AND JOANNY MOULIN
}

In his essay "The Profession and Vocation of Politics," Max Weber contends that three specific qualities are necessary for conducting politics- "passion, a sense of responsibility, judgement" - which charismatic leaders are expected to embody to exercise influence and lead a nation (352). This vision of a "leadership democracy" undergirds the writing of political biography and the making of political biopics, which play out the internal and external debates that arise in the course of a political career, confronting political deciders with strategic choices to be made at times of historical crisis. The collective memory of political figures rests on such iconic historical moments, visually and aurally preserved in archival footage and speeches that have marked public life. While historians originally used political biography to write national history, biographical films now reenact these iconic scenes to capture the historical agency of political leaders. Political biographical films actually serve the process of democracy by adopting a cause-and-effect narrative logic that enhances the agency of political figures. The cinematic biographical narrative unfolds a temporality open to agency, and it thereby reactivates the notion of political power behind those historical moments that have left iconic images.

While the media tends to focus on a politician's public life, including a self-conscious mise-en-scène or performance of their own speeches and actions that aims to convey abstract ideas, political biographies actually delve into the behind-the-scenes political (and personal) process. William H. Epstein contends that "biographical narrative of whatever kind has traditionally been an ally of dominant structures of socioeconomic authority, as have the film industry in general and the industrial, technical, and aesthetic practices of biopics in particular" (2). Although this statement proves accurate as regards classical Hollywood cinema, the scandals that have erupted around some political figures have also prompted a more critical stance. Oliver Stone's JFK (1991) is a case in point, giving credit to conspiracy theories about an alleged secret CIA assassination plot. 
The articles collected in this issue offer insight into other ambiguous cases and beyond the constructed discourse of the self that the proliferation of political biography and biopics in the twentieth century illustrates. As demonstrated by the 2016 election of reality TV star Donald Trump to the American presidency and Barack Obama's 2008 internet campaign, political power increasingly resides in the media circulation of one's image and sound-bites. John Corner and Dick Pels argue that "the 'styling of the self' in politics, the projection of political persona, is partly a matter of choice (a conscious 'branding' exercise designed to sharpen profile) and partly a required reaction to the terms of media visibility that now frame and interpret political action in many countries" (10). Biopics deconstruct the visual discourse of political figures through emphasizing this exercise of self-presentation, drawing attention to every element of their performance, including setting, clothing, makeup, and rehearsed speech.

Situated at the crossroads of two writing modes about history and the subject, political biopics question the political commitments of public figures by probing into their personal character and the social movements of the time. Biopics fuel curiosity about what happens beyond the public stage and the iconic moments: Lincoln (2012) includes long cabinet discussions about how to conduct the war, Selma (2016) details the internal debates between Southern Christian Leadership Conference and Student Nonviolent Coordinating Committee representatives, and W. (2008) views Georges W. Bush's presidency through a psychological lens that interprets all political decisions as the result of a father-son rivalry. In a previous issue of Biography, Glenn Man observes that "a biopic . . . is not so much a film about a life as it is a film about competing and intersecting discourses, with the life itself being simply one of those discourses that is transformed by the work of others" (vi). The political discourse intertwines with the historical and the psychological in biopics, sometimes echoing the conflicts of memory raised by controversial leaders.

Thirty years ago, Hayden White argued in The American Historical Review that film should be considered just as valid a medium as print for historians to express themselves (1193), and roughly at the same time French historian Marc Ferro put that idea into practice by developing a long television series called Histoires parallèles on the French-German channel Arte. It is certain that since the last decades of the previous century the production of biographical films has grown, both in quantity and in quality, to such a point that it has had a considerable impact on our political landscapes. Although we go on speaking of "biopic" out of habit, modern film biographies—or biofilms, as Robert Rosenstone would prefer to say-have very little in common 
with the historical Hollywood biopic of the early twentieth century. The biopics of the Hollywood studio era were very much a latter-day revision of Carlyle's hero-worship, or in any case it was a genre very much steeped in ready-made tropes, from the Horatio Alger myth or rags-to-riches story to Romantic clichés of the great man or genius. We are very far away from these sorts of things today, perhaps because cinema, like other popular arts, has quickly reached maturity and earned its lettres de noblesse as a major art form. Perhaps also the growth of democratic forces in a globalized world has liberated the mental attitudes of the mass of human beings toward political leaders. Whatever the reasons why, modern biographical films have imposed themselves as a political force with a considerable impact in the life of the polis. Remarkably, the cinema no longer waits tamely for political leaders to have become part of history: they are represented on the screen even while they are still in office. Thus, for instance, in Xavier Durringer's La Conquête (2011), Denis Podalydès plays the role of President Sarkozy one year before the end of Sarkozy's electoral mandate.

Whatever the merits of this or that political biofilm, it is impressive to see how film biographies have a freedom of expression that print biographies do not typically possess. This is what could be called the biopic's "critical" freedom, in the sense that what the public and the critics find quite conventional in cinema would certainly be frowned upon in print. Such departures take two principal forms: fictionalization and periodization. Fictionalization is the telling of a factual story in the manner of fiction. Periodization is the focusing on a certain period of the life of the personage only, implicitly or explicitly leaving the others out of the narration to make room for a possible sequel, prequel, or series. When we say "biopic" or "biofilm" we generally mean the fictionalized type as opposed to standard biographical documentaries. Now, in print biographies, fictionalization is in fact taboo, so much so that it is hardly even mentioned, and it has remained so ever since the days of when André Maurois's 1923 biographie romancée of Percy Bysshe Shelley received negative criticism because the text was what we would call "creative nonfiction": like fictionalization in cinema, all the content of this print biography is factual, but the form is that of fiction. In print biographies, creative nonfiction is immediately suspected of factual inaccuracy, whereas in film biographies, fictionalization is not-in part, perhaps, because the use of actors and constructed sets makes the fictionality of the representation so conspicious it escapes the charge of error or duplicity. More exactly, factual inaccuracy is immediately perceived in film, but it is not perceived as a fabrication, perhaps even as a trumpery, as it certainly would in a book. 
A print biography that would stage the life of a political personage using the techniques of showing rather than telling, with extensive dialogue andwhy not?-inner focalization or stream of consciousness would tend to be perceived as a fake, if not as a buffoonery. Why is that? Perhaps because we have always been used to watching historical dramas. In Shakespeare's history plays, for example, there is in fact no suspension of disbelief: hardly any one was ever mad enough to think, even for a split second, that the actor is really Julius Caesar. Neither do we believe that the personage really said the words we hear, or that these asides and soliloquies are his historical thoughts. We are aware that the show is a show from beginning to end, and our aesthetic appreciation of the film is in fact a dialectic process of investigation and judgment going on, while the film lasts, between the images on the screen and our preexisting mental representations of the subject. In print biographies, paradoxically, there is scarcely any such Brechtian distancing effect. An image is false by definition, but a false word remains an abomination. Perhaps this moral orientation is related to the sacredness of the word and the influence of the religions of the book. Perhaps it is because a film always somehow remains entertainment, a popular and a secular art form, because it is "superficial" in a Nietzschean sense-deriving its seriousness precisely from its apparent lack of seriousness. Maybe that is also because a film is technically limited to a short periodization with so many ellipses, so we are more ready to allow it to represent only some aspects of the subject, provided it leaves all the rest to our imagination.

This special cluster of four articles, published by Biography, addresses different types of political biographies through the intersection of film and literature. Film scholar Rémi Fontanel focuses on the representations of French political figures in a series of French television films that have drawn little scholarly attention. Although Napoléon I continues to attract historian filmmakers, French television has recently turned to twentieth-century political figures, following a production strategy aimed at the national market. Fontanel aptly remarks that contemporary television filmmakers turn to biography as a means for further reflection on historical facts and more particularly on the role of political figures in some specific historical moments - such as General De Gaulle during the Algerian War in Je vous ai compris: De Gaulle 1958-1962 (2010). French television is committed to the duty of memory and produces films with a strong didactic purpose.

Nicole Cloarec shows that British filmmakers were more daring when retracing the political career of Margaret Thatcher. The Iron Lady was a controversial character whose personality aroused as many critiques as her policies. Gender affected Thatcher's political style, and filmmakers have chosen 
to humanize the woman behind the iron hand, thereby illuminating different stages in her path to power-including the double bind she faced as a mother determined to pursue her political ambitions. The biopics call attention to Thatcher's self-conscious attitude as a woman in politics, suggesting that her gender influenced her communication style. Interestingly, the films' focus on "womanly" issues undermines Thatcher's political beliefs by turning political convictions into stubbornness.

As an academic who reflects on her own biographical work written in response to a request from a French publisher, Françoise Coste presents an original take on biography. She addresses the difficulties of writing a political biography - a term fraught with preconceived ideas, as she explains. The article is a clever demonstration of how former Hollywood actor Ronald Reagan shrouded himself in the construction of a fictitious reality. Engaging Lou Cannon's biography, President Reagan: The Role of a Lifetime (1991), the author deciphers how Reagan's filmic and media career has interfered with the biographical interpretations of his presidential life. Coste suggests that the "acting metaphor" provides a useful frame for the understanding of Reagan's presidency, building on the confusion between fact and fiction.

In the final article, Gertjan Willems deals with a Flemish production titled Daens (1992), based on a biographical novel by Louis Paul Boon, Pieter Daens (1971). The former Catholic priest Adolf Daens gave his name to the "Daensist movement," which promoted greater social awareness than the Catholic political movement, as well as Flemish emancipation in a predominantly francophone Belgian society. Willems analyzes the political stakes of a biographical film that was produced with public money and therefore subjected to multiple controls on the part of various commissions. Using Adolf Daens's life to write Flemish history, the biography and the biopic became political events raising national issues.

The fours articles of the dossier show that political biopics are national productions, for filmmakers investigate the dark spots of national history through the personal and public careers of prominent figures. Films also spotlight the performative dimension of political life, turning the iconic moments of the past into collective visual memories. 


\section{WORKS CITED}

Corner, John, and Dick Pels. Media and the Restyling of Politics. Sage Publications, 2003.

Epstein, William H., and R. Barton Palmer, editors. Invented Lives, Imagined Communities: The Biopic and American National Identity. State U of New York P, 2017.

Ferro, Marc. Le Cinéma: une vision de l'histoire. Édition du Chêne, 2003.

Man, Glenn. "Editor's Introduction." The Biopic, a special issue of Biography: An Interdisciplinary Quarterly, guest-edited by Glenn Man, vol. 23, no. 1, 2000, pp. v-x.

Rosenstone, Robert A. History on Film/Film on History. Kindle ed., Pearson Longman, 2006.

Weber, Max. "The Profession and Vocation of Politics." Weber: Political Writings, edited by Peter Lassman and Ronald Speirs, Cambridge UP, 1994, pp. 309-69.

White, Hayden. "Historiography and Historiophoty." The American Historical Review, vol. 93, no. 5, 1988, pp. 1193-99. 